\title{
The foreign language anxiety in learning German and the effects of total physical response method on students' speaking skill
}

\author{
Adnan Oflaz ${ }^{\text {a }}$ (iD \\ ${ }^{a}$ Ondokuz Mayls University, Samsun 55139,Turkey
}

\section{APA Citation:}

Oflaz,A. (2019). The foreign language anxiety in learning german and the effects of total physical response method on students' speaking skill. Journal of Language and Linguistic Studies, 15(1), 70-82.

Submission Date:27/06/2018

Acceptance Date:07/01/2019

\begin{abstract}
There are some factors affecting the development of the speaking skill in the process of learning a foreign language. One of the factors hampering the speaking process is the anxiety state of students. A student who thinks they will make mistakes in classroom activities or while talking to a person speaking that language experiences anxiety at a certain degree. They get anxious, even become afraid prior to speaking activities. This problem covers the whole language learning process in time and affects it adversely. In this study, after the anxiety levels of the students in language learning were detected, the Total Physical Response Method was employed to reduce speaking anxiety, to support language learning with actions, and to ensure learning through practice and experience. Before the applications, the speaking anxiety pretest and oral communication placement test were applied. The pre-test points for speaking skills of students in the experimental group were obtained with the application of an A2 level 3-step oral examination from Goethe Institute. Considering the speaking skill exam post-test points the students got after the application of the Total Physical Response Method, it can be seen that the lowest point was 64 and the highest was 86. It can be seen in the results of the speaking anxiety posttest and the anxiety levels that the anxiety levels of three students with a high level (112+) decreased to medium (61-111). The anxiety points of the other seven students in the experimental group decreased but their anxiety level remained the same (medium). After the applications, students were also observed to be more willing to speak German and eager to take turns to speak.
\end{abstract}

(C) 2019 JLLS and the Authors - Published by JLLS.

Keywords: German; foreign language; anxiety; speaking anxiety; speaking skill

\section{Introduction}

One of the factors hindering the process of speaking is anxiety. Students thinking that they will make a mistake in class or while talking to people speaking that language experiences anxiety at some certain level. They are anxious and even afraid before speaking activities. This problem covers the whole foreign language learning and affects it negatively. According to Oxford (1999), students in foreign language classes can experience state anxiety when they have to speak, but the anxiety disappears as their foreign language skills get better and levels go upper. But, in some students the anxiety experienced

\footnotetext{
* Corresponding author. Tel.: +90-362-312-1919,ext.6254

E-mail address: aoflaz@omu.edu.tr
} 
turns into a persistent one and never disappears. Once the anxiety experienced in foreign language classes come to a state of continuity, it affects performance and success in foreign language negatively (Batumlu \& Erden, 2007).

\subsection{Literature review}

\subsubsection{Anxiety in Language Teaching}

"Anxiety is the subjective feeling of tension, apprehension, nervousness, and worry associated with an arousal of the autonomic nervous system" (Horwitz, Horwitz \& Cope, 1986, p.125). "Anxiety is a psychological construct, commonly described by psychologists as a state of apprehension, a vague fear that is only indirectly associated with an object" (Hilgard, Atkinson \& Atkinson, 1971, cited in Scovel, 1991,p. 18). "In the context of foreign or second language learning, anxiety refers to the feeling of being very worried about the new language which is being learnt" (Ekmekçi, 2018, p.158). Foreign language learners, who feel anxious, have symptoms of mouth dryness, concern, throb, and worry, avoidance of speaking and difficulties in language learning. "According to Horwitz and Cope (1986), the anxiety about foreign languages should be dealt with apart from those experienced in other courses. According to them, the process of learning a foreign language comprises of very complicated experiences and requires the learners to associate their perceptions, beliefs, emotions and behaviors with the classroom" (cited in Aksoy, 2012,p.19). Students have the anxiety of feeling ashamed before the teacher or their friends. This anxiety can make learners get discouraged, lose faith in their abilities, escape from participating in classroom activities, and even give up the effort to learn a language well (Na, 2007). Studies in a variety of language learning context have found that approximately one third of students studying a foreign language experience at least a moderate level of foreign language anxiety (Aida, 1994; Horwitz, Horwitz \& Cope, 1986; Horwitz, 2001; Le, 2004; cited in Luo, 2014). Negative effects of anxiety has been identified in many studies (Horwitz 1986; MacIntyre \& Gardner,1994;Tang,2005). Significant negative correlations were determined between foreign language anxiety and academic achievement (Coulombe, 2000; Elkhafaifi, 2005; Yan \& Horwitz, 2008; Salehi\&Marefat, 2014).

It has also been seen that the problem of inability to speak in cases of oral communication are psychological. Namely, the fact that a foreign language student is shy may imply avoidance in communication situations, too. In this regard, the subject of shyness shouldn't be ignored. Shyness is the state of having difficulty in building good relations with others. Generally, avoiding eye contact, getting away from frightening situations, speaking in a low voice and playing with hands and face during speaking are psychomotor indications of shy people.

\subsubsection{The Importance of the Speaking Skill}

Regarding foreign languages learning, those signs (words) used in oral and written communication are of key importance. Because, as long as the words of the target language aren't known, thoughts won't be formed in that language and thus thoughts can't be expressed afterwards. Naturally, this leads to a lot of oral communication problems. Even if someone learning a foreign language has enough knowledge of grammar, they can't use the language due to insufficiency of vocabulary. On the other hand, concentrating on teaching grammar in foreign language courses hinders the development of other skills even though it provides students with the knowledge of the structural elements of that language by learning the language through rules. This problem appears mostly in oral communication, namely while using the language, speaking the target language.

Among the primary problems in language teaching, inability to develop basic language skills (listening, speaking, reading and writing) adequately as well as grammar ranks first. In order to be able to master a targeted foreign language, these four basic language skills must be developed at certain levels. According to Neuner (1995), language is first of all a means of communication, and, in language 
teaching, the grammar dimension of this means must be taught not solitarily and "separately" but along with the four basic language skills (listening, speaking, reading and writing) without ruling out sociocultural and pragmatic elements. Basic language skills are divided into two as receptive skills (Rezeptive Fertigkeiten) - listening and reading skills - and productive skills (Produktive Fertigkeiten) -speaking and writing skills, and also as oral and written (Steinig \& Huneke, 2002). These skills have a great place and importance in language teaching; however, the "speaking" skill is the one which needs to be elaborated as a productive skill among the four basic language skills. Since "speaking" covers embodying sounds and grammar or both in respect of structure, participation as both a receptor and a producer, not only sound production but facial expressions and gestures as well, it is considered a fourdimensional (productive, perceptive, audial and visual) action (Widdowson, 1978). During speaking, a student tries to articulate language elements correctly and master the emphasis, intonation and rhythm in the language. Similarly, they manage to listen to others and comprehend what they listen to, and thus to talk and come to an understanding. The most important of all, the student's anxiety about speaking begins to lessen and it encourages them to build confidence. This and such natural activities keep students' interest alive towards the course and prevents them from being demotivated (Demirel, 2011). In order to gain the speaking skill, enough vocabulary, the rules of the language and the articulation of words must be known. In general meaning, these are in the scope of "knowledge" in respect of teaching. This knowledge would only transform into production through a "skill". For example, people who have never driven a car learn theories about cars and engines in a driving school, but can't yet drive. However, their command on cars increases as they drive. As they drive, the knowledge gains meaning and their skill to drive a car arises. There is a similar situation in speaking in a foreign language, too. Having the theoretical knowledge does not mean speaking that language. Even though there is knowledge, the skill hasn't developed and turned into a linguistic production yet. Unless psychomotor skills are stimulated, communicative skills do not develop and speaking does not take place successfully.

\subsection{The Total Physical Response Method}

Total Physical Response (TPR) is a language teaching method built around the coordination of speech and action; it attempts to teach language through physical (motor) activity. (Richards \& Rodgers, 2001). This Method was developed by James Asher a psychology professor at San Jose State University in 1965. "It is a method which, through physical (motor) activities which fulfill oral orders, aims to develop listening comprehension skill first, and in the next step, oral narration skill at the beginner level without any forcing" (Demircan, 2002, p.221). Asher (1969) believes language production will develop from comprehension and therefore learners will speak when they are ready. TPR aims to stimulate learning through physical movement. The basic principle is that the L2 is taught by giving commands that require the learner to physically move to complete (Jones et al.,2015). It aims to teach a language through physical activities. The defenders of this method emphasize that learning a second language by adults takes place parallel to the first language acquisition by a child. The general features of the method are as follows: The initial material of the class is the teacher's voice, mimics and activities instead of books and lecture notes. What were learned in the previous lesson are repeated, recalled and activated. Later, the teacher himself does the target activity by the help of the objects or materials existing in the classroom or those he has brought, and clearly tells what they are doing. In this way, the formation of the comprehensible input is rendered.

The comprehensible input accelerates learning by reducing the stress triggering an individual's fear or anxiety about not being able to learn. Asher emphasizes that the perceptions of the left brain strengthens thanks to this method (Marm, 2013). The Total Physical Response Method is linked to a memory theory in psychology named "the Trace Theory", which defends that the more often or densely a memory relation is traced, the stronger a memory connection will be and the more probable to 
remember it. This could be done orally, e.g. by repetition, and/or by motor activity relation. The cooccurrence of oral exercise type of tracing activities supported by motor activity increases the probability of successful remembrance. In Asher's Total Physical Response Method, vocabulary and grammatical structures compared to other language skills are emphasized. Students who learn first the pronunciations of the words and structures in the imperatives later learn how to write and read them (Larsen-Freeman, 2000). Words are taught one by one or in groups in subjects. Thus, the gesture done kinesthetically will remind the word, and therefore the statement and the link forming in the brain will get stronger along with gesture repetition. As a result, a long-term and persistent behavioral alteration, namely learning, will occur. The requirement of learning a foreign language by practice and experience, which is emphasized by foreign language teaching experts, will be fulfilled to some extent. And in a student learning by practice and experience, the anxiety of learning a language will diminish and learning will begin to give happiness. Along with the diminishing of the language learning anxiety, the motivation and achievement level of the student will go up. Dopamine, a neurotransmitter excreted in case of success, renders the mood of happiness to arise. With this aspect, dopamine plays a rewarding role for the brain. "In cases when a person feels afraid or excited, the hypothalamus excretes adrenaline and corticotropin hormones. Following the secretion, these hormones get to the hypophysis and the hypophysis makes the suprarenal glands secrete cortisol. By mixing such stress hormones as adrenalin and noradrenalin with blood, cortisol harms the protein synthesis in the cells carrying out the memory functions" (Gür, 2010,p. 45).

During the last ten years, the relationship between anxiety and language proficiency and achievement in German learning has been examined. There are a few research focused on exploring the anxiety level in learning German language and its relationship to some variables (Yılmaz \& Maden 2016; Ağar, 2014). In this studies it was researched whether there is a relationship between the anxiety level and gender and whether the previously learned language creates anxiety during the process of learning a new foreign language, and which language skill causes anxiety for individuals most and what the reasons of this anxiety are.

\subsection{Research questions}

1. What is the foreign language anxiety level of students' studying at the Department of German Language Teaching?

2. Is there a correlation between the students' foreign language anxiety levels and their gender?

3. Does the The Total Physical Response Method have a positive effect on reducing the level of foreign language anxiety of the students?

\section{Method}

\subsection{Sample / Participants}

Participants were 61 (50 females and 11 males) students studying at at the formal and evening education programs of the German Language Education Department of the Faculty of Pedagogy of Ondokuz Mayıs University. Of the 61 participant students, $82 \%$ (n:50) were female. And the participant male students were $18 \%$ (n:11).

\subsection{Instrument $(s)$}

In this study, the pretest-posttest design with a control and an experimental group as the experimental model are used. At the data collection stage, a " Foreign Language Classroom Anxiety Scale (FLCAS)," 
was conducted to the students $(\mathrm{N}=61)$ in order to determine the anxiety states experienced in the process of German language speaking skill development and their causes. The Total Physical Response Method was applied to the students in the experimental group (N:10) two hours per week for six weeks.

\subsection{Data collection}

At the data collection stage, "Foreign Language Classroom Anxiety Scale" was conducted to the students in order to determine the anxiety states experienced in the process of German language speaking skill development and their causes. Developed by Horwitz and Cope (1986), this scala was translated into Turkish by Aydın (1999) and was adapted to German by us. FLCAS has been specified to be 'valid' and 'reliable' by many researchers abroad (Aida, 1994; Horwitz, Horwitz ve Cope 1986; Price, 1991). The internal consistency of the original scale was found to be 0.93 , and the correlation coefficient in consequence with the test-retest eight weeks after to be $0.83 \mathrm{p}=0001$ (Sarıül, 2000). The internal consistency of the translated version of the questionnaire was .91. The scale conducted to 61 students who studied at the 1st, 2nd and 3rd grades at the formal and evening education programs of the German Language Education Department at the Faculty of Pedagogy at Ondokuz Mayıs University and its Cronbach-Alfa reliability coefficient was found 0.75 .

Following the determination of the speaking anxiety levels, in order to measure the speaking skill levels of the students in the experimental group (n:10), the students were asked the questions of "Goethe Institute A2 Level Oral Exam" before the applications. In the first part, the students were asked to introduce themselves in accordance with the keywords given in the questionnaire and then to answer at least two questions. In the first part, the students were asked to introduce themselves (Name, age, city, place of residence, languages, occupation and hobby and when to go to sleep and wake up what to do after breakfast, total: 10 questions). In the second part, they were asked open ended questions with interrogative adverbs such as "How often", "What time" ..., "How long", "Why", "How" ( 5 W questions). And in the third part, they were asked to give directions for addresses so as to test their skills to give information, make suggestions to others and make dialogs. In the classroom where the test was conducted, a place was designated priorly, and they were asked to direct a friend to that place (using words such as go left, go right, go straight, go straight, turn off).

\subsubsection{Procedures}

The Total Physical Response Method was applied two hours per week for six weeks. In the application phase, the actions done were shown gradually in German so that all the students could understand, and also the verbs used and demonstrated by the teacher were tried, practiced, and articulated clearly by the students. Implementation process: the verbs aimed to teach:

Der Lehrer (teacher): - ich gehe ans Fenster (I go to the window), jetzt mache ich das Fenster auf (I open the window now), Ich atme tief ein (I take a deep breath), Ich atme aus (Ibreathe out), und jetzt mache ich das Fenster zu (and now I close the window).

Der Lehrer (teacher): Ich gebe dir die Zeitung (I give you the newspaper), du liest jetzt die Zeitung (you're reading the newspaper now), Ich bringe meine Zahnbürste (I bring my tooth brush), Ich putze mir die Zähne (I brush my teeth).

In order to improve listening skill, the target words and sentences are articulated clearly and slowly alongside gestures. The fact that the things heard in the target language can't be interpreted, that the words said in sentences can't be known mean that decoding can't be accomplished. On the other hand, this causes a comprehensible input not to come into existence. For these reasons, in order to ensure the linguistic inputs (words) to become intelligible, in accordance with the levels, the sentences were made in such a tone of voice that they could hear the articulation clearly. An expression supported simultaneously by gestures makes a connection between the relevant motion and the target word used 
at that moment in students' minds. In order to ensure the knowledge to be permanent, the implementation was repeated all over the same once more by the teacher. Later, a student was told such imperatives in the target language as :

Der Lehrer (teacher): "Geh ans Fenster bitte" ("Please go to the window")

Der Student (student): „Ich gehe ans Fenster” (“I go to window”)

Der Lehrer (teacher) :"Mach das Fenster auf und atme tief ein und wieder aus" ("Open the window and breathe deeply and give it back")

Der Student (student): "Ich mache das Fenster auf, "Ich atme tief ein und wieder aus"" ("I open the window, I take a deep breath, and I breathe out")

Der Lehrer ( teacher) : "Mach das Fenster zu“" ("Close the window").

Der Student (student): "Ich mache das Fenster zu", ("I close the window")

Der Lehrer ( teacher) : "Gib mir bitte die Zeitung!" ("Please give me the newspaper")

Der Student (student): "Ich gebe die Zeitung" ("I give the newspaper")

Der Lehrer (teacher) : "Gib mir die Zahnbürste...!" ("Give me the toothbrush")

Der Student (student): "Ich gebe Ihnen die Zahnbürste", ("I give toothbrush")

Der Lehrer (teacher) : "Putze dir die Zähne bitte...!" ("Please brush your teeth”)

Der Student (student): "Ich putze mir die Zähne“ ("I'm brushing my teeth”)

and the student fulfilled the instruction and repeated what they did in the target language. The student acts, goes to the window, opens the window and takes a deep breath, pretends to be reading a newspaper and brushing their teeth simultaneously with making those statements. Afterwards in the lesson, videos relevant to the subjects from actual life are watched, and new sentences are made and supported by motions. In this way, the target structures and words are acquired by supporting them with psychomotor skills, by using them properly in respect of situational-contextual scope, and by experiencing. For a student, inhaling and exhaling deeply while learning the verbs "tief einatmen" and "ausatmen" (take a deep breath and breathe out) and expressing them in German personally contributes them to code the action they are doing cognitively, to make them meaningful for themselves, and to transfer them to the long-term memory by coding. The interpretation of the knowledge learned by the person is of great importance for the permanency of the knowledge, too. The meaningful knowledge coded by psychomotor skills and muscle movements changes into performance (Performanz) and lingual production at the end of the process.

\section{Results}

The foreign language anxiety levels of the subjects were determined by the administration of the FLCAS. The possible anxiety scores for this scale range from 32 to 160 . "For this study 27. item "i feel more tense and nervous in my language class than in my other classes" was eliminated from the questionnaire because the subjects of this study were chosen among foreign language learners and since all the classes they participated in the program were "language classes" this item would not be appropriate for their situation" (Aydın, 1999, p.54). Therefore, possible scores of the translated version of FLCAS in the study ranged from 32-160. 
Table 1. The Foreign Language Anxiety Pretest Points and Levels of Students

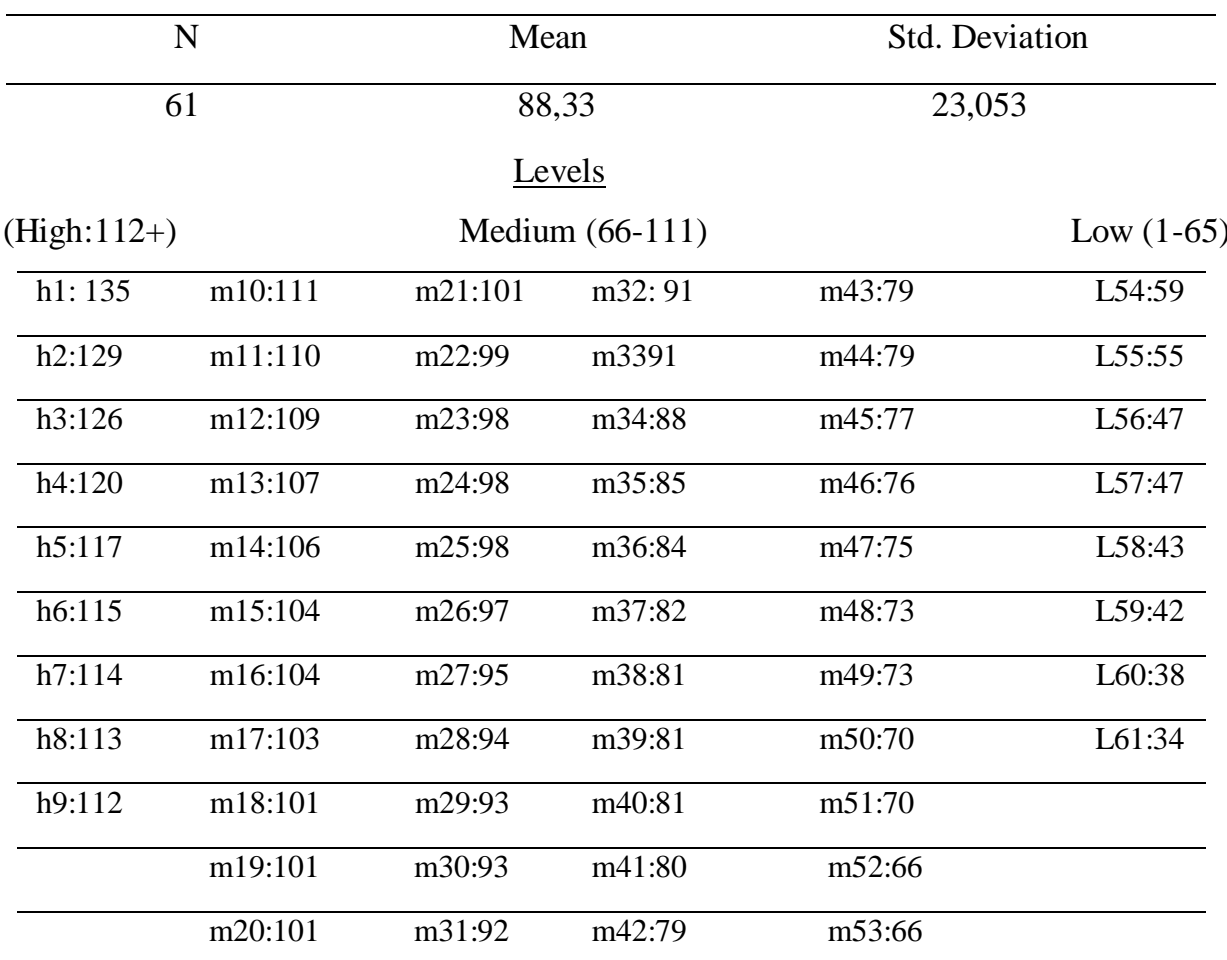

The results of the data analysis reflected that, for the subjects of the present study, the anxiety scores ranged between 34 and 135. The range and degree of foreign language anxiety of 61 intermediate level language learners were determined by using the questionnaire FLCAS (Foreign Language Classroom Anxiety Scale), the students' answers to the questionnaire were considered. Observing the pretest results of the Foreign Language Classroom Anxiety Scale, it can be seen that, of the 61 participant students, eight (8 students) (13,12\%) had low level (Low:1-65); forty-four (44 students) (72,13\%) had medium level (Medium:66-111) and nine (9 students) (14,75\%) had high level (High:112+) anxiety.

Table 2. Foreign Language Classroom Anxiety Levels as to Gender

\begin{tabular}{lcccc} 
Gender & N & Mean & Std. Deviation & Std. Error Mean \\
\hline Female & 50 & 88.90 & 22.821 & 3.227 \\
Male & 11 & 85.73 & 25.052 & 7.554 \\
\hline
\end{tabular}

Of the 61 participant students, $82 \%$ (n:50) were female. The anxiety mean of the female students was $\bar{X}=88,90$. It can be seen that they experience medium level anxiety in the process of learning German. And the participant male students were $18 \%$ (n:11). In the results of the poll, it can be seen that the male students experienced anxiety at a lower level $\bar{X}=85,73$ compared to the females. 
Table 3. Foreign Language Classroom Anxiety Levels as to Nationality

\begin{tabular}{lcccc}
\hline Nationality & N & Mean & Std. Deviation & Std.Error Mean \\
\hline Türkish & 5 & 92.91 & 19.502 & 2.654 \\
German & 7 & 53.00 & 17.607 & 6.655 \\
\hline
\end{tabular}

Observing the anxiety situations of the students born in the countries where German is the official language and those who learned German as the second foreign language, the anxiety level mean of the seven Germany origined students $(11 \%)$ was found $\bar{X}=53$. This rate indicates that the anxiety level of those students was low. Because those students studied in Germany and were able to speak German well, those students do not experience speaking anxiety. The anxiety mean of the fifty-four student (89\%), who were learning German as the second foreign language, was $\bar{X}=92,93$. This rate was slightly higher than the medium level (Medium:66-111).

Table 4. Foreign Language Classroom Anxiety Levels as to the Studying Grades

\begin{tabular}{lcccccc}
\hline & $\mathrm{N}$ & Mean & Std.Deviation & Std.Error & Lower Bound & Upper Bound \\
\hline 1st Grade & 26 & 80.04 & 23.844 & 4.676 & 70.41 & 89.67 \\
\hline 2nd Grade & 18 & 97.44 & 16.912 & 3.986 & 89.03 & 105.85 \\
3rd Grade & 17 & 91.35 & 24.202 & 5.870 & 78.91 & 103.80 \\
Total & 61 & 88.33 & 23.053 & 2.952 & 82.42 & 94.23 \\
\hline
\end{tabular}

Observing the anxiety levels of the students as to the grades they were studying, it was found that the anxiety mean of the 1 st grade students ( $\mathrm{n}: 26$ ) was $\bar{X}=80,04$ (medium level), of the 2 nd grade students was $\bar{X}=97,44$ (medium level) and of the 3 rd grade students was $\bar{X}=91,35$ (medium level). It can be seen that the anxiety point mean for the 2 nd grade students was higher $\bar{X}=97,44$ than the others, and was close to the high level anxiety.

Table 5.The Speaking Skill Pretest-Posttest Scores of the Students and Comparison of Speaking Skill Levels

\begin{tabular}{lcccc}
\hline & & \multicolumn{2}{c}{ Test Scores of } & $\begin{array}{c}\text { Speaking Skill } \\
\text { Post-implementation }\end{array}$ \\
& & & & \\
& Pre-implementation & Posttest & Speaking \\
N & Pretest & Speaking & Skill Level \\
\hline S.1 & 35 & Skill Level & 64 & pass \\
S.2 & 30 & fail & 71 & medium \\
S.3 & 42 & fail & 85 & good \\
S.4 & 28 & fail & 74 & medium \\
S.5 & 30 & fail & 77 & medium \\
S.6 & 27 & fail & 70 & medium \\
S.7 & 25 & fail & 68 & pass \\
S.8 & 36 & fail & 75 & medium \\
S.9 & 39 & fail & 81 & good \\
S.10 & 40 & fail & 86 & good \\
\hline
\end{tabular}


In order to determine whether the students used speaking skill, which is a productive skill, at A2 level, they were applied "Goethe-ZertifikatA2: Start Deutsch 2"oral exam, which is made up of three stages. The answers given to the questions asked in that three staged exam by the students in the experimental group were graded out of 100 by paying regard to such criteria as grammar, use of appropriate words and use of fluent language use. The levels as to the intervals of points are 100-90 Points: very good (pekiyi); 89-80 Points: good (iyi); 79-70 Points: medium (orta); 69-60 Points: pass (geçer); 59-0 Points:fail (başarısız).

Before starting the application of the Total Physical response Method, the students were given a speaking skill placement test through "Goethe-ZertifikatA2: Start Deutsch 2". Checking the test scores of the students, it can be seen that the lowest score was 25 and the highest was 42 . According to these scores, all of the students in the experimental group (n:10) failed in the exam. The Total Physical Response Method was conducted to the students two hours per week for six weeks. By this method, the following points were considered: a) students interpreted cognitively what they learned,b) structures were coined by taking psychomotor skills and motion as base instead of classical memorization, and c) students did experienced and expressed them.

Checking the results of the speaking skill test conducted at the end of the implementation, it can be seen that the lowest score was 64 and the highest was 86. It can be seen that there was an increase in the students' success levels; that three students enhanced their "fail" (nicht bestanden) speaking skill levels up to "good" (gut), five of them up to "medium" (befriedigend), two of them up to "pass" (ausreichend).

Table 6.The Comparison of the Anxiety Test Points and Anxiety Levels of the Students Anxiety Test Points and Anxiety Levels of Experimental Group

\begin{tabular}{ccccc}
\hline \multicolumn{2}{c}{ Pretest } & \multicolumn{2}{c}{ Posttest } \\
N & Points & Levels & Points & Levels \\
\hline S.1 & 101 & medium & 76 & medium \\
S.2 & 111 & medium & 79 & medium \\
S.3 & 76 & medium & 68 & medium \\
S.4 & 135 & high & 82 & medium \\
S.5 & 93 & medium & 81 & medium \\
S.6 & 115 & high & 75 & medium \\
S.7 & 117 & high & 84 & medium \\
S.8 & 110 & medium & 83 & medium \\
S..9 & 101 & medium & 75 & medium \\
S.10 & 91 & medium & 73 & medium \\
\hline
\end{tabular}

Reviewing the speaking anxiety pretest points of the students in the experimental group, it can be seen that three students experienced high level (112+) (S4:135, S6:115, S7:117), eight of them medium level speaking anxiety (66-111), and the anxiety levels of some those students were very close to the high level (S2:111,S8:110). According to the data obtained, nearly half of the participant students experience high level speaking anxiety. The teacher, who barely acted like a director, sets up a learning environment far from tension through their voice, mimics and the activities they are doing. The fact that teachers do the targeted activity themselves beforehand and expresses what they are doing in a way that every student can understand reduces anxiety and ensures the comprehensible input to form. In order to determine whether the application reduced the levels of speaking anxiety of the students in the experimental group, the Foreign Language Classroom Anxiety Scale was reconducted. Accordingly, it can be seen that the anxiety levels of three students experiencing high level anxiety (S4:82, S6:75, S7:84) reduced to medium level; that there had been a reduction in the anxiety points of the other students but their anxiety levels stayed at "medium level". 


\section{Discussion}

It is a fact that the speaking skill cannot be improved through teaching methods in which grammar teaching and writing activities are intensive. Classroom activities relevant to other language skills definitely make contributions relatively, but the speaking skill could only be improved through speaking exercises, namely, by speaking in the target language, by oral production in communication situations. In this sense, the method chosen for the lesson should be supported by speaking activities, students should be encouraged to make use of the active vocabulary they have, and also their inactive vocabulary should be activated. In this course, taking their anxiety states into consideration, students should be supported by learning situations and learning activities in which they will feel comfortable. Decrease in the language learning anxiety of students could only be possible by determination of the circumstances causing anxiety and activities intended for resolving the problem. For this reason, in this study, following the determination of the students' language learning anxiety levels, the "Total Physical Response Method" was used to reduce anxiety in language learning, particularly in speaking, to support language learning by movements, and to ensure learning by practice and experience.

\section{Conclusions}

Considering the arithmetic means $(\mathrm{X}=88,33)$ of the students' (n:61) pre-implementation speaking anxiety levels, it can be seen that they experienced medium level (66-111) anxiety speaking in German. However, it was identified that $14,75 \%$ of those students experienced high level (112+) anxiety, that the mean of the male students' anxiety level in speaking was $X=85,75$ and of the females' was $X=88,90$ considering the anxiety levels as to gender. According to these data, male students experience anxiety at a lower rate than females. The mean of speaking anxiety of the students form Germany was lower $(X=53)$. Due to the fact that they have studied in Germany previously, those students' command on the language is at a high level. Naturally, those students, who do not have problems in speaking in German, are not anxious in oral communication. Considering the anxiety levels as to the grade of studying, the levels at the 2nd $(X=97,44)$ and $3 r d(X=01,35)$ grades were higher than at the 1st grade. The Total Physical Response Method was applied to the students in the experimental group (n:10) two hours per week for six weeks. The Students learned the meaning of words and structures with the help of body movements. Students have also reinforced these vocabulary and grammatical structures using psychomotor skills. This study thus provides language learning by experience. Considering the results of the experiment, it was seen that the students increased their lower pretest speaking test scores and enhanced their speaking skill levels. Reviewing the speaking anxiety proof positive results of the students in the experimental group, the points of the totally five students, those whose anxiety levels were high (S4:135, S6:115, S7:117) and those who experienced anxiety very close to high level (S2:111, S8:110), increased following the conduction and their anxiety levels went down to medium level. Any difference in the anxiety levels of the other students wasn't identified. Following the conduction, it was observed that the students were more willing to speak in German, that they didn't avoid speaking situations, and that they asked to speak more in the courses of other areas. The Total Physical Response Method in connection with the "Trace Theory" used in memory studies supported the development of students' speaking skills through verbal exercises supported by motor activity in this study. 


\section{References}

Ağar, A.N. (2014). Emotion-centric psycho-linguistic barrierrs that affect the ability of speaking in german learning as a second language ( master's thesis). Selçuk University.

Aida, Y. (1994). Examination of Horwitz, Horwitz, and Cope's construct of foreign language anxiety: The case of students of japanese. Modern Language Journal, 78, 155-168. DOI:10.2307/329005.

Aksoy, M. (2012). The relationship between anxiety, shyness, strategy and academic achievement in foreign language learning (Doctoral dissertation). Ankara University.

Asher, J. J. (1969). The total physical response approach to second language learning. The Modern Language Journal,53(1), 3-17.

Aydin, B. (1999). A study of sources of foreign language classroom anxiety in speaking and writting classes (Doctoral dissertation). Anadolu University.

Batumlu, D. Z., \& Erden, M. (2007). The relationship between foreign language anxiety and english achievement of yildız technical university school of foreign languages preparatory students. Journal of Theory and Practice in Education, 3 (1), 24-38.

Demircan, Ö. (2002). Yabancı dil öğretim yöntemleri. İstanbul: Der Yayınevi.

Demirel, Ö. (2011). Yabancı dil öğretimi; dil pasaportu, dil biyografisi, dil dosyası. Ankara: Pegem Yayınları.

Ekmekçi, E. (2018). Exploring turkish efl students' writing anxiety. The Reading Matrix: An International Online Journal, 18 (1), 158-175. ERIC Number: EJ1177762.

Elkhafaifi, H. (2005). Listening comprehension and anxiety in the Arabic language classroom. Modern Language Journal 89(2), pp. 206-220.

Gür, Ö. (2010). The impact of learning trough laughing on student success in the teaching of german as a foreign language for adults (Doctoral dissertation). İstanbul University.

Horwitz, E. K. (2001). Language anxiety and achievement. Annual Review of Applied Linguistics, 21, 112-126.

Horwitz, E. K., Horwitz, M. B. \& Cope, J. (1986). Foreign language classroom anxiety. Modern Language Journal, 70, 125-132.

Jones, C; Lees, M; , Donohue, N., \& Smith, K. (2015). Teaching spoken english at junior high school: a comparison of tpr and ppp. The Language Teacher, 39.1 January/February.

Larsen-Freeman, D. (2000). Techniques and principles in language teaching, Oxford University Press New York.

Le, J. (2004). Affective characteristics of american students studying chinese in china: a study of heritage and non-heritage learners' beliefs and foreign language anxiety (Ph.D. dissertation). The University of Texas at Austin.

Luo, H. (2014). A measure of chinese language learning anxiety: scale development and preliminary validation. CASLAR, 3(2): 147-174, DOI 10.1515/caslar-2014-0009.

Marım, E. (2013). The applicability of foreign language teaching theories in german teaching as second foreign language (Ph.D. dissertation). Ankara University.

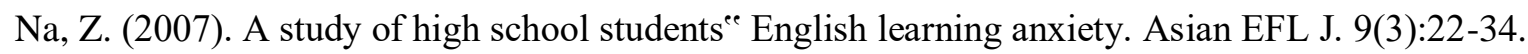


Neuner, G. (1995). Methodik und methoden, überblick, in: Bausch Christ / Krumm (Hrsg.) Handbuch fremdsprachenunterricht. Tübingen: Franke Verlag.

Oxford, R. (1999). Anxiety and the language learner: new insights. Jane, A.(Ed.), Affect in language learning. Cambridge University Press.

Price, M. L. (1991). The subjective experience of fl anxiety: interviews with highly anxious students. Horwitz, E.K. \&Young D.J. Language anxiety. London: Prentice-Hall International (UK), 87-97.

Richards, J. C., \& Rodgers, T.S. (2001). Approaches and methods in language teaching. USA: Cambridge University Press.

Salehi M., Marefat F. (2014). The effects of foreign language anxiety and test anxiety on foreign language test performance. Theory and Practice in Language Studies, 4(5), 931-940. DOI:10.4304/tpls.4.5.931-940

Sarıül, H. (2000). Trait anxiety and foreign language anxiety and thei reffects on learners' foreign language proficiency and achievment (master's thesis). Boğaziçi University.

Scovel, T. (1991). The effect of affect on foreign language learning: a review of the anxiety research. In Horwitz, E.K., \& Young, D. J.(eds.) Language anxiety: From theory and research to classroom implications. Englewood Cliffs, NJ: Prentice Hall, pp. 15-24.

Steinig, W., \& Huneke, H.W. (2002). Deutsch als fremdsprache: eine einführung. 3.überarbeitete und erweiterte auflage. Berlin: Erich Schmidts. Pp 109-135.

Tang Meiling. (2005).Survey and study of non-English major undergraduates' English learning anxiety in class. Taituan Normal University Journal (social science edition) 4, 145-146.

Widdowson, H.G. (1978). Teaching language as communication. Oxford University Press.pp.57-109

Yan, X. \& Horwitz, E.K. (2008). Learners' perceptions of how anxiety interacts with personal and instructional factors to influence their achievement in English: A qualitative analysis of EFL learners in China. Language Learning. 58(1), 151-183.

Y1lmaz, D., \& Maden, S. S. (2016). A research on anxiety attitudes of german language teaching department teacher candidates during the language learning process. Trakya Üniversity Journal of Education, (6) 2, 201-211. Retrieved from http://dergipark.gov.tr/trkefd/issue/24152/256291. 


\section{Almanca öğreniminde konuşma kaygısı ve tüm fiziksel tepki yönteminin öğrencilerin konuşma becerisine etkileri}

\section{$\ddot{O} \mathbf{z}$}

Yabancı dil öğrenimi sürecinde konuşma becerisi gelişimini etkileyen bazı faktörler bulunmaktadır. $\mathrm{Bu}$ faktörlerden biri öğrencilerin kaygı durumudur. Sınıf içindeki aktivitelerde veya hedef dilde konuşan kişilerle konuşurken hata yapacağını düşünen bir öğrenci belirli düzeyde kaygı yaşamaktadır. Konuşma aktivitelerinden endişelenmekte, hatta korkmaktadır. Bu sorun, zamanla yabancı dil öğreniminin bütününü kapsamakta ve olumsuz etkide bulunmaktadır. Bu çalışmada öğrencilerin dil öğrenme kaygı düzeyleri tespit edildikten sonra konuşma kaygısını azaltacak, dil öğrenimini hareketlerle destekleyecek ve yaparak yaşayarak öğrenmeyi sağlayacak "Tüm Fiziksel Tepki Yöntemi” uygulanmıştır. Uygulamalar öncesi konuşma kaygısı öntesti ve sözlü iletişim seviye belirleme sınavı uygulanmıştır. Deney grubu öğrencilerinin konuşma becerisi öntesti puanları Goethe enstitüsünün A2 seviyesindeki 3 aşamalı sözlü sınavı uygulanarak elde edilmiştir. Tüm Fiziksel Tepki Yöntemi uygulamaları sonrası konuşma becerisi sınavı son test puanlarına bakıldığında öğrencilerin en düşük 64 en yüksek 86 puan aldığı görülmektedir. Konuşma kaygısı son testi ve kaygı düzeyleri sonuçlarından yüksek seviyede (112+) kaygı sahibi 3 öğrencinin (d4:82, d6:75,d7:84) kaygı düzeyinin orta seviyeye (61-111) düştüğü görülmektedir. Deney grubundaki diğer yedi öğrencinin kaygı puanları düşmüş, ama kaygı düzeyleri aynı düzeyde (orta düzeyde) kalmıştır. Deney grubu öğrencilerinin sözlü sınavda aldığı puan artmış, yapılan konuşma kaygısı anketi ile kaygı düzeyleri yüksek olan öğrencilerin uygulama sonrasında kaygı düzeylerinin orta seviyeye düştüğü belirlenmiştir. Uygulamalar sonrası öğrencilerin Almanca konuşmaya daha da istekli oldukları, konuşmak için daha fazla söz aldıkları da gözlemlenmiştir.

Anahtar sözcükler: Anahtar sözcükler: Almanca, yabancı dil, kaygı, konuşma kaygısı, konuşma becerisi

\section{AUTHOR BIODATA}

Adnan Oflaz is working as Dr. Instructor in the Department of Translation and Interpretation at Ondokuz Mayls University. He received his MA (2008) and his PhD degree (2015) in German Language Teaching from Ondokuz Mayıs University, where he teaches undergraduate German courses. He has published widely in various refereed international journals and presented papers in national and international conferences. His fields of interests are neurolinguistics, foreign language teaching, language teaching methods, methods and approaches in vocabulary teaching 